UDC 316.334.56+614.1

DOI: $10.21668 /$ health.risk/2018.3.16.eng

Read

online

\title{
CREATION OF HEALTH-ORIENTED CITY SPACE AS A WAY TO MANAGE POP- ULATION HEALTH RISK
}

\author{
A.V. Prokofyeva ${ }^{1}$, N.A. Lebedeva-Nesevrya ${ }^{1,2}$ \\ ${ }^{1}$ Perm State University, 15 Bukireva Str., Perm, 614990, Russian Federation \\ ${ }^{2}$ Federal Scientific Center for Medical and Preventive Health Risk Management Technologies, 82 Monastyrskaya \\ Str., Perm, 614045, Russian Federation
}

Nowadays intense urbanization is taking place, cities with a number of dwellers over a million and urban agglomerations appear, and it calls for new ways how to preserve and improve health of urban population who are exposed to various risk factors, primarily environmental and behavioral ones. One of such ways could be development of a city as health-oriented physical, social, and semantic space; that is, it should be an environment that has natural, material, socio-cultural and other resources and they are used to create possibilities for individuals and social groups to preserve and improve their health. Parameters of a physical component in health-oriented space and their possible indicators can be found in foreign concepts and international projects ("healthy city", "active city", "age-friendly city"), as well as in Russian management practices ("Creation of comfortable urban environment" project, a concept of urban space quality). This article focuses on a detailed system of indicators that can be applied to assess whether a health-oriented urban environment is welldeveloped; the system is based on risk-oriented approach and includes two groups of indicators. The first one comprises indicators that describe a health-preserving component in urban space that allows to control health risk factors better; the second one includes indicators that are related to a health-improving component that helps to improve health and to promote stability. As morbidity and mortality among urban population vary greatly in their structure depending on countries and regions, health-oriented urban space should be created taking into account health peculiarities of population living on a specific territory.

In other words, detected leading causes for mortality and morbidity among urban population in Russia as well as manageable risk factors that cause them should serve as grounds for a creation of such a body-space urban environment that will be oriented at reduction in negative impacts exerted by chemical contamination of the environment on population health (planting, alternative transport infrastructure, compliance of drinking water sources with sanitary-epidemiologic requirements, quality of water supplies and distribution systems); such system will also provide conditions for sufficient physical activity and health nutrition.

Key words: urban space, health-oriented space, healthy city, health risk, risk management.

High urbanization rates in the second half of the $20^{\text {th }}-$ beginning of the $21^{\text {st }}$ century, typical for most countries of the world, resulted in a fact that today more than half of the population lives in cities $(54.7 \%$, according to the World Bank). In developed countries, this indicator in 2017 was at the level of $70-80 \%$ (in Germany, urban population share made $76 \%$, in France: $80 \%$, Canada: $82 \%$, Great Britain: $83 \%$, Japan: 94\%). According to Federal State Statistics Service (Rosstat), in Russia the urban popu- lation exceeds significantly the rural $(74.3 \%$ vs. $25.7 \%$, respectively), and since 1959 the urban population share in our country has increased by more than $20 \%$.

An intensive development of cities, emerging "million-plus cities" and formation of urban agglomerations, often counting of tens of millions dwellers (for example, the number of Japanese agglomeration of Tokyo-Yokohama is over 37 million people), made it relevant to find new ways for preserving and improving health

(C) Prokofyeva A.V., Lebedeva-Nesevrya N.A., 2018

Natalya A. Lebedeva-Nesevrya - Doctor of Sociological Sciences, Associate Professor, Head of Laboratory for Social Risks Analysis Techniques, Professor at Sociology Department (e-mail: natnes@ fcrisk.ru; tel.:+7 (342) 237-25-34).

Alyona V. Prokofyeva - senior lecturer at Sociology Department (e-mail: prokofyeva.alena@gmail.com; tel.: +7(922) 243-48-09). 
of urban residents exposed daily to various risk factors. The latter include environmental (air pollution from toxic emissions of motor vehicles, noise pollution of urban environment, pollution of drinking water with industrial wastewaters) and social factors (atomization of urban community, a dominant of "depersonalized" interaction of citizens, high social inequality, mostly sedentary lifestyle). Modern cities architecture has a negative impact on urban population health: typical buildings, plurality of identical repetitive elements (for example, windows of multi-storey buildings), poor greening of new areas.

Numerous scientific studies show that citizens health has its own distinct features - in cities there is a higher risk of developing chronic diseases [1], a higher chance of being injured in a car accident [2], urban lifestyle characterized by irregular meals, eating fast food and low physical activity increases risk of overweight [3] and diseases of cardiovascular system [4]: in cities with a sizeable population number, communication of infectious diseases is probably higher than in rural areas [5].

Growth of urban population and multiplicity of factors that affect citizen health mainstreamed the task of urban development so that physical and social environment would contribute as high as possible to preservation and improvement of residents' health. This task was most shown up in the initiatives of the global movement "Healthy Cities" under the auspices of the World Health Organization (WHO), whose principles, among other things, are human-centered urban planning, increasing population resilience to adverse external effects of environment, fighting inequality regarding health [6].

In addition to the "healthy city" concept, WHO advocates the need to develop cities as spaces that are friendly to older people ("agefriendly city"), children ("child-friendly city") and people with disabilities ("disabledaccessiblecity"). The common ground between all of these concepts is that they are aimed primarily at prioritizing health in urban policies and combining the efforts of administrations at various levels, specialized institutions and local community to create in cities the conditions for living and personal development, ranging from its active and healthy evolvement (in case of children), and ending with productive and healthy aging (in case of the elderly). The integral principles here are equal access and fairness that defines an approach to a city as a physical and social space in which equal opportunities for saving and improving one's health by all categories of citizens must be ensured.

The idea of health-oriented city space ("health-friendly city"), like the concept of healthy cities, is the result of two interdirectional movements in the field of healthcare and public health, and in the field of urban planning and urban design. The first movement is related to social factors influence on population health. The first attempts of this movement were observed in the work of Health Councils in Italy of the Renaissance, the works and activities in the field of social hygiene by Frank I.P., the creation of public health system of Great Britain by the initiative of E. Chadwick [7], as well as the medical, anthropological and political activities of R. Virchow in the field of social medicine. These scientists and public figures work led to the formation and evolvement of socio-medical health paradigm, in which medicine is a social science destined to interfere in social and political life to solve health problems. Such an insight that improving social conditions in some cases makes it possible to extend human life faster and more efficiently than medical progress has also been associated with studying the effects of not only biological, but also social roots on epidemics, as well as analysis of link between low health indicators of slum dwellers and their living conditions.

The second trend, which promoted healthy urban space idea, is associated with a working (social, to a wider extend) issue, creation of public organizations in a number of countries (the Social Science Association in the UK, the American Social Science Association in the USA, the Union for Social Policy in Germany, etc.), having united the academic community and politicians for expert guidance in the field of social reform. This resulted, firstly, in the emergence of a number of urban studies in the field of living conditions and lifestyle of working and lower classes $[8,9]$; secondly, led to urban planning movements (B.W. Richardson's "City of Health" [10], the concept and movement of a 
'Garden City' by G. Ebenezer [11], the City Beautiful movement [12], the movement for middle class "settlements" in poor urban areas for educational and charitable purposes [13], etc.). The central idea was to achieve the highest possible life quality through certain principles in the field of urban planning. However, the practice of implementing a number of urban projects such as "Garden City", as well as projects for demolition of slums and construction of highrise buildings as a solution to the problems of poverty, led to the insights that physical urban environment significance in maintaining and improving health were supplemented by such socio-cultural factors as an importance of social ties, preservation of local community, etc. Thus, the problem of health turns out to be equally related to the issues of urban planning, selforganization of urban communities, as well as to medical services.

In various fields of expertise and social practice, approaches to healthy city will focus on various aspects. Therefore, public health experts L. Dahl and T. Hancock, the creators of "Healthy Cities" project, suggested using a holistic approach to the healthy city concept, which in addition to public health included the ideas from sociology, urban geography, urban planning, ecology, politics, economics, philosophy and many other disciplines [14]. The need for a systematic approach to analyzing citizens' health in the context of urban space is promoted by Sharp Roux A.V., emphasizing the "system essence" of both the 'city' and 'public health' [15].

City is an artificial habitat [16], a complex, self-regulating system, on the one hand, producing hazards to human life and health, and on the other, capable of providing effective ways to counter these hazards. Hence, the creation of a "safe urban environment" (for example, within the framework of "Safe City" program, operating in many cities of Russia and designed to contribute to improving security "on streets and roads", to resist "criminal and terrorist threats").

A safe urban environment presupposes safety of dwellers in terms of all sorts of threats, primarily of external nature. It is not only about citizen life and health, but also about their rights and freedoms, material interests, personal information, etc. Urban space safety implies the conditions created to minimize various risk factors effects on public health, i.e. the environment allows inhabitants to preserve health. The concept of health-oriented city space integrates, along with the health-preserving aspect, the healthimproving one, which is explained by differentiating health factors into resistance factors (antirisk) that have a positive effect on health, increase body's resistance to external threats, and risk factors that increase probability of developing diseases. With regard to public health, it is expected that the effectiveness of anti-risk factors will be higher than the elimination of regular risk factors. Also the key point here is that in medicine the paradigm of pathogenesis is being substituted for the paradigm of salutogenesis [17]. For the former, the origin and source of diseases, as well as their prevention, is relevant, while for the latter it is a search for sources of physical and mental health and ways to improve it. Thus, within the framework of health-oriented city space, health-preserving components allow for better control over health risk factors, and health-strengthening components - for improving health, i.e. promoting factors of resistance.

Health-oriented city space is understood to mean physical, social, and semantic environment of a city, which, with its resources (natural, material, socio-cultural, etc.) creates opportunities for individuals and social groups to maintain and strengthen their health.

The physical component of healthoriented city space is a body-space environment, "city design" [18], "first order reality" [19], including, for example, health care system infrastructure, parks and public gardens, pedestrian zones and squares, outdoor recreation and sports equipment (street sports mini-centers), etc. In social aspect, health-oriented city space is a world of social relations in which people interact with each other, create social facts and at the same time conform their behavior with coercive influence of these facts, in a word, construct social reality and objectify it. We are talking about social institutions, norms, values and behavioral practices aimed at preserving health, urban communities and institutions that contribute to the development of healthy lifestyles and selfpreserving behavior through their activities. The semantic aspect of city space reflects it as a "field of values", as a construct, as a valuesemantic structure, and its analysis should be 
based on phenomenological method, and precede the construction of socio-urban theories. City residents "themselves create an environment for their life" [20] endowing both physical and social objects of this environment with these or other values. Hence, it seems important not only to hold the existing infrastructure in a city (both physical and social) that is designed to preserve health, but also whether this infrastructure is perceived by citizens as suitable, affordable, and attractive to implement health preservation and promotion practices.

This study is focused on healthy-oriented city space as the world of physical objects, the physical (real) environment, the body-space environment of city residents, and analyzing its completeness in modern cities requires a clear system of criteria to evaluate the development of certain environmental components and set the direction for its further improvement.

One of the most comprehensive approaches to assessing the formation degree of a health-oriented city space was developed by the ideologists of "Healthy Cities" movement $T$. Hancock and L. Dahl, who proposed 11 city parameters for assessing its "health" degree [14]. These parameters describe not only the physical, but also the social space (for example, "community strength" or "participation and control", reflecting the degree of local communities involvement in making meaningful decisions for a city and an ability to support citizens).

The physical component of healthoriented space within the framework of the healthy city concept is proposed to be characterized, first, through cleanliness, safety and quality of physical environment, including the provision of housing. Indicators of this parameter may be, for example, air pollution level, green spaces share in a city's territory, share of housing that meets national or international standards. Moreover, physical environment influence is taken into account not only at the somatic, but also at the mental health and psychological comfort level, which is reflected, for example, in the concept of therapeutic landscapes [21]). Secondly, through possibilities for citizens to satisfy their demand for medical care, which is measured using a number of indicators: physical accessibility of outpatient and high-tech care, specialized rehabilitation institutions, etc. Third, through de- velopment of infrastructure aimed at meeting basic needs, whose indicators may be availability of grocery stores focused on different nutritional needs, or availability of drinking water.

A number of indicators for healthoriented city space development are proposed in another project of the World Health Organization "Active City", aimed at stimulating active lifestyle of citizens, including physical education and sports [22]. As indicators for measuring the development level of an artificially created body-space environment ("built environment"), it is proposed here to use an accessibility of sports infrastructure (number of gyms, fitness clubs, swimming pools, street gym sites, etc.), as well as the development level of cycling and pedestrian infrastructure (toll and free bike paths, number of bike parking lots, and length and illumination of footpaths, including in forest-park areas, flexibility of pedestrian areas to the needs of limited mobility populations groups).

The basic definition of a city friendly to older people (age-friendly city) as having an "inclusive and accessible environment (both physical and social) that optimizes opportunities for maintaining health ... and ensuring rightful life quality for people as they're aging" [23] makes the indicators proposed under this concept noteworthy. This is, firstly, the accessibility of green spaces and public places adapted to the needs of the elderly (for example, enough "seating areas"), secondly, the availability of sidewalks that are safe for health of the elderly (wide, free from high curbs or other obstacles and road crossings), thirdly, the development of urban hygienic infrastructure (for example, access to public toilets), fourthly, the provision of elderly people with medical care [24].

Indicators related to city environment health-focus are used by the British Economist Intelligence Unit (EIU), which makes annual rating of cities in the world by Habitat Safety Index ("safe cities index") [25]. For example, when calculating the index, safe and quality food available for citizens is taken into account. Moreover, the 2017 report points out serious problems of small North American cities, called "food deserts", where locals have to eat fast food or low-quality stuff from small stores [26]. Also, when calculating the index, accessibility criteria of health facilities, atmospheric air and drinking 
water quality, proportion of population living in slums, road and transport infrastructure quality, and development of pedestrian-friendly urban environment are used. The latter implies not just a hypothetical opportunity for a pedestrian to go through a certain route, but such a quality and level of comfort of pedestrian network that the preferred way to get around the city is not a personal or public transport, but a walk. This is facilitated by a high level of safety (separation from auto-road), road surface quality, greening of a territory in the direction of walking, etc. [27].

Another EIU compiled rating - the global cities "liveability" rating contains indicators related to health of permanent residents of a city and its guests, such as humidity and temperature rating, climate discomfort for travelers, accessibility of sports facilities, road network and public transport quality, availability of good quality housing [28].

The concept of "global cities" [29], even more focused on economic aspects of city life, in some methodologies takes into account urban environment quality, since it is a factor in attracting labor resources to a region. Thus, the Global Power City Index, developed by the Institute for Strategic Urban Development with the support of Mori Memorial Fund (Japan), includes such indicators as: viability of a city (average rent rate for housing, variety of retail stores and catering and others), environment (CO2 emissions, density of sulfur dioxide and nitrogen dioxide, percentage of renewable energy, percentage of waste disposal, level of greening, comfortable temperature, etc.) and availability (punctuality and scope of public transport, deaths due to road traffic accidents) [30, 31]. Unlike most other approaches, the Global Power
City Index takes into account also the subjective assessments - particular perceptions of urban space quality by residents [32].

Health oriented city space is taken into account in the concepts of sustainable cities ("sustainable city", "eco-city"), slow cities ("cittaslow"), cities with low carbon emissions ("zero-carbon city", "low carbon city") [33], cities without cars ("car-free city") [34] and garbage [35]. International Environmental City Standards developed by the experts of the British Columbia Institute of Technology and the American nonprofit organization Ecocity Builders imply the achievement of certain levels in terms of indicators [36]:

- medial distance between housing, work and places for everyday goods and services purchases;

- functional qualities of construction materials in both residential and commercial buildings;

- environment friendly transport system (percentage of pedestrians, cyclists, public transport passengers and drivers of personal vehicles);

- air quality inside and outside premises;

- greenhouse gas emissions;

- quantity and quality of water supplies available;

- availability of healthy food (percentage of plant-based diet).

The approaches being developed in the Western Europe and North America aimed at minimizing anthropogenic pollution of urban environment and reducing its impact on health of residents cannot be directly transferred to the Russian practice of urban management due to significant differences in socio-economic, sociocultural and climatic parameters of the countries

\footnotetext{
${ }^{1}$ Passport of the priority project "Creation of comfortable urban environment" / Approved by Presidium of the Council on Strategic Development and Priority Projects under the President of the Russian Federation (Minutes No. 10 of November 21, 2016). Available at: http://static.government.ru/media/files/WoyaBZP00CYeyfDQ2Ai2tJ18zZHt7HnS.pdf (access date: 20.08.2018) Passport of the priority project "Creation of comfortable urban environment" / Approved by Presidium of the Council on Strategic Development and Priority Projects under the President of Russian Federation (Minutes No. 5 of April, 18, 2017). Available at: http://static.government.ru/media/files/JEnYAAfDkMAyyIAjsAxDzkxXGPuaEJSu.pdf (access date: 20.08.2018)

${ }^{2}$ On approval of the Method for determining Quality Index of urban environment for municipalities of the Russian Federation: Order of the Ministry of Construction of Russia No. 1494/pr of October 31, 2017. Available at: http://www.minstroyrf.ru/upload/iblock/ddc/prikaz-1494pr.pdf (access date: 20.08.2018)
} 
[37]. As a result, certain developments in assessing the focus of urban space on preservation and strengthening health of citizens are proposed within the framework of national science and management practice.

So, in 2016, Russia adopted a priority project "Creation of comfortable urban environment"1, aimed, inter alia, at reducing the incidence rate of the population in urban areas. The Russian Federation subjects are rated annually by the quality of urban environment assessed using the "quality index of urban environment for municipalities"2. The calculating method of this index involves characterization of six types of space (housing and adjacent areas, greenery and water spaces, street infrastructure, social leisure infrastructure and public business infrastructure and adjacent areas, citywide space) by 5 criteria (safety, comfort, environmental friendliness, identity and diversity, modernity of environment), each one represented by a certain indicator in accordance with the named types of space. The health of a city can be described, for example, through such indicators as share of public green areas (parks, gardens, etc.) in the area of all green spaces in general, pedestrian accessibility index, safety of movements near institutions of social services for citizens, accessibility of sports grounds for citizens, etc.

As part of "urban space quality" concept $[38,39]$ Ilyina I.N. identifies a number of parameters that can be attributed to the physical aspect of a health-oriented city space: health, safety, affordability of quality housing and services, accessibility to urban public recreation and open spaces, a variety of transport accessibility options, waste management, minimization of environmental pollution and this process management, adaptation to climate changes and natural disasters mitigation [40]. The urban environment quality is proposed to be assessed according to three classification blocks: quality of "framing" (basic) infrastructure of a city, quality of urban space, and safety and comfort of living, and availability of services for all sociodemographic categories of population.

A number of approaches emphasize the quality assessment of town-planning objects viability from the point of their socio-psychological successfulness. For example, criteria for analyzing planning decisions, divided into characteris- tics of socio-psychological safety and sociopsychological comfort, and satisfaction with living environment, can include the presence of identifiable boundaries of public and private space, residential areas planning following the "closed spaces" principle, possibility for visual viewing of a territory, yard areas arrangements, landscaping, sports grounds, level of provision with elements of social and engineering infrastructure, extending functions of structural components in residential environment, and others [41].

The considered approaches are complex, focused on ensuring the high quality of citizens' life and stable urban development. Preserving and strengthening urban population health is a more local task, the specific tools and developed systems of indicators are required to ensure effective management of citizen health. One of the solutions to this problem may be a system for assessing the degree of formation of a healthoriented city environment, following a riskbased approach.

The health of urban environment in the context of managing public health risks means that the physical space of a city is, firstly, focused on minimizing the impact of environmental and behavioral factors on citizens health, and secondly, increasing human body resilience, preventing "the root causes of poor health" [42], "the disease origins" [43]. For example, antinoise screens on roads within the city limits or public places that are free from smoking allow you to keep residents healthy, reducing the risks caused by acoustic and chemical pollution of environment. Outdoor exercise complexes or bicycle lanes are more aimed at improving citizens' health.

Since the structure of urban population morbidity and mortality has the signified country and regional peculiarities, the creation of a city's health-oriented space should be carried out taking into account the specific health aspects of a particular territory' inhabitants. Thus, the leading cause of urban population mortality in Russia are diseases of circulatory system (the share of this category causes in total citizens mortality in 2017 , according to Rosstat, was $48 \%$, including of ischemic heart disease which made up $26 \%$ of cases, of cerebrovascular disease: $15 \%$ ). The contribution of this cause to mortality in the 
largest cities of Russia is almost the same [44]. The controlled risk factors for circulatory diseases include unhealthy lifestyles (smoking, low levels of physical activity, malnutrition [45]), chemical pollution of natural environment (air and drinking water [46]), as well as sociopsychological factors (for instance, depression, various anxiety symptoms and disorders [47]). Malignant tumors are the second most common cause of death among urban population in Russia $(16.9 \%)$, including malignant neoplasm of digestive organs: $6.4 \%$, respiratory organs: $3 \%$, female genital organs and mammary gland: $26 \%$.

According to the US National Cancer Institute [48], the leading modifiable risk factors for cancer are anthropogenic pollution of environment with carcinogenic substances and low level of self-preserving behavior (alcohol abuse, smoking, improper diet, untimely access to a doctor). The main cause of morbidity among urban population in Russia is respiratory disease. So, in 2016, the prevalence of acute upper respiratory tract infections, per 100 thousand city dwellers, was $25251.6^{3}$ cases [49]. The leading risk factors for development of respiratory diseases in modern cities are chemical pollution of atmospheric air [50], living conditions quality, and also smoking [51].

Hence, developing a modern Russian city as a health-oriented one implies a targeted activity of municipal authorities and local communities towards creating such a body-space environment, which will, first of all, reduce the level of effects on citizen health from environment chemical pollution, and provide conditions for an adequate level of physical activity and healthy diet.

To assess the degree of health-oriented city space formation in practice it is proposed to use a system of indicators (Table). This assessment can be done within the framework of monitoring the quality of urban living environment, socio-hygienic monitoring and the system for monitoring risk factors for non-communicable diseases provided for in the draft Strategy for
Formation of a Healthy Lifestyle of Population, Prevention and Control of Non-Communicable Diseases for the period up to 2025 developed by the Russian Federation Ministry of Health [52].

Developing a city as a health-oriented one involves not only the definition of indicators for physical space formation degree that contributes to health preservation and strengthening, but also to establishment of their target values, which should be a guideline for implementation of effective territorial management tasks. One of the approaches may be to choose target parameters in the "healthiest" cities in the world. For example, according to the World Cities Culture Report prepared by BOP Consulting Editorial Team in 2015, the share of public green areas in Sydney (Australia) and Vienna (Austria) made 46\%, in Shenzhen (China): 45\% [53].

In Russia, today, the system of regulations has partially developed in the formation of health-oriented space of a city (see Table). For example, Code 42.13330.2016 "Urban planning. Planning and Development of Urban and Rural Settlements. The updated version of SNiP 2.07.01-89" ${ }^{\prime}$ defines green area of a microdistrict (a quarter) for residential area multidwelling development at the level of at least $25 \%$ of a quarter's area. In addition, it indicates the need for landscaping at least $50 \%$ of yard areas with trees and shrubs. In March 2018, the Ministry of Sports of Russia approved the criteria for the minimum allowable provision level with sports facilities based on the indicator "onetime capacity of a sports facility" of 122 persons per 1,000 of population. This indicator was calculated on the basis of the set strategic goal for physical culture and sports development in Russia - attracting the entire working-age population (under 79 years old) and children (aged from 3 years) to regular (3 hours per week) physical culture and sports activities by 2030 .

In some regions and cities of Russia (Ulyanovsk Region, Tver, Omsk), the concepts and development programs for cycling, bike transport and bike-cycling infrastructures, including separate target indicators, have been

\footnotetext{
${ }^{3}$ Health care in Russia. 2017 / Stat. Sat Rosstat. Moscow, 2017, 170 p.

${ }^{4}$ Code 42.13330.2016 Urban planning. Planning and Development of Urban and Rural Settlements. Updated version of SNiP 2.07.01-89. Code: electronic fund of legal and regulatory and technical documentation. Available at: http://docs.cntd.ru/document/456054209 (access date: 20.08.2018)
} 
Indicators for the formation degree of health-oriented city space

\begin{tabular}{|c|c|c|c|}
\hline No & $\begin{array}{l}\text { Risk factors for } \\
\text { urban popula- } \\
\text { tion health }\end{array}$ & $\begin{array}{c}\text { Characteristics of urban } \\
\text { space }\end{array}$ & Indicator \\
\hline \multirow[t]{2}{*}{1} & \multirow[t]{2}{*}{$\begin{array}{l}\text { Atmospheric air } \\
\text { chemical pollu- } \\
\text { tion }\end{array}$} & Green spaces areas & \begin{tabular}{|l} 
Green spaces area of public use, per inhabitant \\
$\left(\mathrm{m}^{2}\right)$
\end{tabular} \\
\hline & & $\begin{array}{l}\text { Formation degree of } \\
\text { alternative transport } \\
\text { infrastructure }\end{array}$ & $\begin{array}{l}\text { Share of roads equipped with dedicated lanes for } \\
\text { public transport in the total length of local roads } \\
(\%) \\
\text { Ratio of the length of roads equipped with lanes } \\
\text { for cyclists to the total length of local roads } \\
\text { Number of public bicycle parking places, per } 1 \\
\text { inhabitant } \\
\text { Number of parking spaces in the adjacent bicycle } \\
\text { parking, per } 1 \text { resident }\end{array}$ \\
\hline \multirow[t]{2}{*}{2} & \multirow[t]{2}{*}{$\begin{array}{l}\text { Drinking water } \\
\text { chemical con- } \\
\text { tamination }\end{array}$} & $\begin{array}{l}\text { Compliance of drinking } \\
\text { water supply sources } \\
\text { with sanitary and epi- } \\
\text { demiological require- } \\
\text { ments }\end{array}$ & $\begin{array}{l}\text { Share of surface sources for centralized drinking } \\
\text { water supply having no sanitary protection zone }(\%)\end{array}$ \\
\hline & & $\begin{array}{l}\text { Quality of water supply } \\
\text { and distribution net- } \\
\text { work }\end{array}$ & $\begin{array}{l}\text { Share of water pipes provided with water purifi- } \\
\text { cation and disinfection treatment }(\%) \\
- \text { Share of sewer networks requiring replacement } \\
(\%) \\
-\begin{array}{l}\text { Share of treatment facilities requiring capital } \\
\text { repairs }(\%)\end{array} \\
\text { Share of sewage treatment facilities equipped } \\
\text { with wastewater sludge treatment }(\%)\end{array}$ \\
\hline 3 & $\begin{array}{l}\text { Sedentary } \\
\text { lifestyle }\end{array}$ & $\begin{array}{l}\text { Formation degree of } \\
\text { infrastructure for phys- } \\
\text { ical culture and sports }\end{array}$ & $\begin{array}{l}\text { Number of sports facilities of various types, per } \\
100 \text { thousand people } \\
\text { One-time capacity of sports facilities of various } \\
\text { types, per } 10 \text { thousand people }\end{array}$ \\
\hline 4 & Improper diet & $\begin{array}{l}\text { Formation degree of } \\
\text { healthy nutrition infra- } \\
\text { structure }\end{array}$ & $\begin{array}{l}\text { Provision of spaces for retail and catering, per } \\
1,000 \text { people } \\
\text { Number of public catering enterprises providing } \\
\text { social catering services }\end{array}$ \\
\hline
\end{tabular}

approved. However, the values and indicators proposed in the context of national regulatory documents cannot be considered as targets in the long term, since they are aimed at ensuring a minimum level of health-oriented city.

In general, the urgent task is to strengthen the development focus of Russian cities on preserving and strengthening the citizen health, on integrating the decisions on green areas ar- rangement into the system of priority actions, creating a healthy nutrition infrastructure and physical activity for all categories of citizens, and ensuring a safe environment. A considerable problem here is the lack of criteria worked out for the formation of a health-oriented city environment, and their low integration into performance indicators of municipal programs. The synthesis and discussion of the best practices for 
organizing various components of healthoriented city environment both in Russia and abroad is of relevance.

The health-focus of a modern city space is not just a way to improve people's living conditions quality, but a key to a successful socioeconomic development of a city, a way to accumulate its human potential. Solving the problem of developing a health-oriented city environment requires the consolidated actions of municipal authorities, expert community, business entities, public organizations and population. In addition, the ability of urban space to provide opportunities for preserving and strengthening citizens' health means, it's formed not only at the physical, but also at the social and symbolic levels, i.e. integrated development.

Funding. The present article was funded from the Russian Federation President grant in government support for young Russian scientists - Doctors of Science (project MD-281.2017.6).

Conflict of interest. The authors state that there is no any conflict of interest.

\section{References}

1. Eckert S., Kohler S. Urbanization and health in developing countries: a systematic review. World Health \& Population, 2014, vol. 15, no. 1, pp. 7-20. DOI: 10.12927/whp.2014.23722

2. Welle B., Li W., Adriazola C., King R., Obelheiro M., Sarmiento C., Liu Q. Cities Safer by Design. Urban Design Recommendations for Healthier Cities, Fewer Traffic Fatalities. World Resources Institute, 2015. Available at: http: //www.wri.org/publication/cities-safer-design (20.08.2018).

3. Christiani Y., Byles J.E., Tavener M., Dugdale P. Do women in major cities experience better health? A comparison of chronic conditions and their risk factors between women living in major cities and other cities in Indonesia. Global Health Action, 2015, vol. 8, no. 1, pp. 1-9. DOI: 10.3402/gha.v8.28540

4. Mozaffarian D., Hao T., Rimm E.B., Willett W.C., Hu F.B. Changes in diet and lifestyle and long-term weight gain in women and men. The New England Journal of Medicine, 2011, vol. 364, pp. 2392-2404. DOI: 10.1056/NEJMoa1014296

5. Rocha L.E., Thorson A.E., Lambiotte R. The Non-linear Health Consequences of Living in Larger Cities. Journal of Urban Health, 2015, vol. 92, no. 5, pp. 785-799. DOI: 10.1007/s11524-0159976-x

6. Healthy Cities Vision. World Health Organization. Available at: http: //www.euro.who.int/en/health-topics/envionment-and-health/urban-health/who-european-healthy-citiesnetwork/healthy-cities-vision (20.08.2018).

7. Sklyarova E.K. Edvin Chedvik: preventivnaya ideya i obshchestvennoe zdravookhranenie [Edwin Chadwick: preventive idea and public health]. Gumanitarnye $i$ sotsial'nye nauki, 2010, no. 2, pp. 5057 (in Russian).

8. Booth C. Life and labour of the people in London. Available at: https://archive.org/details/lifeandlabourpe02bootgoog (20.08.2018).

9. Balch E.G. Review: Hull House Maps and Papers: A Presentation of Nationalities and Wages in a Congested District of Chicago, Together with Comments and Essays on Problems Growing Out of the Social Conditions. Publications of the American Statistical Association, 1895, vol. 4, no. 30, pp. 201203. DOI: $10.2307 / 2276290$

10. Richardson B.W. Modern sanitary science - a city of health. Van Nostrand's Eclectic Engineering Magazine, 1876, no. 14, pp. 31-42. Reprinted from Nature, 1875, no. 12, pp. 523-525. Available at: http:

DOCS/rich'son.htm (20.08.2018) //urbanplanning.library.cornell.edu/

11. The Garden City: Past, present and future. Ed. by S.V. Ward. London, 2005, 240 p.

12. Wilson W.H. The City Beautiful Movement. Baltimore, The Johns Hopkins University Press, $1989,365 \mathrm{p}$.

13. Wade L.C. Settlement Houses. Encyclopedia of Chicago. Chicago Historical Society, 2004. Available at: http: //www.encyclopedia.chicagohistory.org/pages/1135.html (20.08.2018). 
14. Hancock T., Duhl L. Promoting Health in the Urban Context. WHO Healthy Cities Papers No. 1. Copenhagen, Denmark, FADL Publishers, 1988, 54 p.

15. Diez Roux A.V. Health in cities: is a systems approach needed? Cadernos de SaúdePública, 2015, vol. 31, no. 1. Available at: http: //www.scielo.br/scielo.php?script=sci arttext\&pid=S0102311X2015001300009 (20.08.2018).

16. Zaborova E.N., Islamova A.F. Gorod kak sotsial'noe prostranstvo [The city as a social space]. Sotsiologicheskie issledovaniya, 2013, no. 2, pp. 97-100 (in Russian).

17. Lindström B., Eriksson M. Salutogenesis. Journal of Epidemiology \& Community Health, 2005, vol. 59, no. 5, pp. 440-442. DOI: 10.1136/jech.2005.034777

18. Mikhailov S.M., Mikhailova A.S., Nadyrshin N.M. Dizain goroda: osnovnye etapy istoricheskogo razvitiya [City design: milestones of historical development]. Vestnik Orenburgskogo gosudarstvennogo universiteta, 2014, vol. 166, no. 5, pp. 4-9 (in Russian).

19. Bourdieu P. Sotsiologiya politiki [Sociology of Politics]. Moscow, Sotsio-logos, 1993, 336 p. (in Russian).

20. Frolov A.V., Sukhodol'skaya N.P. K fenomenologii gorodskogo prostranstva [Towards a phenomenology of city space]. Vestnik MGSU, 2010, vol. 3, pp. 394-399 (in Russian).

21. Bell S.L., Foley R., Houghton F., Maddrell A., Williams A.M. From therapeutic landscapes to healthy spaces, places and practices: A scoping review. Social Science and Medicine, 2018, vol. 196, pp. 123-130. DOI: 10.1016/j.socscimed.2017.11.035

22. Edwards P., Tsouros A.D. A healthy city is an active city: a physical activity planning guide. WHO Regional Office for Europe, 2008. Available at: http: //www.euro.who.int/document/E91883.pdf (20.08.2018)

23. Kano M., Rosenberg P.E., Dalton S.D. A Global Pilot Study of Age-Friendly City Indicators. Social Indicators Research, 2018, vol. 138, no. 3, pp. 1205-1227. DOI: doi.org/10.1007/s11205-0171680-7

24. Global Age-friendly Cities: a Guide Global Age-Friendly Cities: a guide. France, WHO, 2007. Available at: http: //www.who.int/ageing/publications/Global age friendly cities Guide English.pdf (20.08.2018)

25. Safe Cities Index Interactive Tool. 2017. Available at: http: //safecities.economist.com/safecities-index-2017-interactive-tool (20.08.2018).

26. Safe cities index 2017: security in a rapidly urbanizing world. A report from The Economist Intelligence Unit. 2017. Available at: https: //dkf1ato8y5dsg.cloudfront.net/uploads/5/82/safe-cities-indexeng-web.pdf (20.08.2018).

27. Shamsuddin S., Abu Hassan N.R., Bilyamin S.F.I. Walkable Environment in Increasing the Liveability of a City. Procedia - Social and Behavioral Sciences, 2012, vol. 50, pp. 167-178. DOI: 10.1016/j.sbspro.2012.08.025

28. The Global Liveability Index 2018. A free overview. A report by The Economist Intelligence Unit. 2018. Available at: http: //www.eiu.com/public/thankyou_download.aspx?activity=download\&campaignid=Liveability2018 (20.08.2018).

29. Sassen S. The Global City: New York, London, Tokyo. Princeton: Princeton University Press, 1st ed., 1991, 416 p.

30. Global Power City Index 2017. Summary. Institute for Urban Strategies, The Mori Memorial Foundation. 2017. Available at: http: //mori-m-foundation.or.jp/pdf/GPCI2017_en.pdf (20.08.2018).

31. Ichikawa H., Yamato N., Dustan P. Competitiveness of global cities from the perspective the Global Power City Index. Procedia Engineering, 2017, vol. 198, pp. 736-742. DOI: 10.1016/j.proeng.2017.07.125

32. Aleksandrova A.Yu. Reitingi global'nykh gorodov mira kak turistskikh destinatsii i mesto v nikh Moskvy [Ranking of world global cities as tourist destinations and Moscow particular position]. Regional'nye issledovaniya, 2014, no. 3, pp. 122-130 (in Russian).

33. Theme Cities: Solutions for Urban Problems. Ed. by W.K.D. Davies. London, Springer (GeoJournal Library No. 112), 2015, 615 p.

34. Crawford J.H. Carfree Design Manual. International Books, 2009, 600 p.

35. Global Principles For Zero Waste Communities. Zero Waste International Alliance: the official website. Available at: http: //zwia.org/standards/zw-community-principles/\#ref3 (20.08.2018). 
36. Ecocity Focus Lab: Final Report Bcit Downtown Campus, 2016. Available at: http: //www.ecocitystandards.org/ecocity-standards-headline-indicators/ (20.08.2018).

37. Voloshinskaya A.A., Komarov V.M. Kontseptsii ekogoroda: rekomendatsii dlya Rossii [Ecocity concepts: recommendations for Russia]. Terra economicus, 2017, vol. 15, no. 4, pp. 92-108 (in Russian).

38. Kyvelou S., Filho W.L., Sustainable management and urban space quality in the Mediterranean: Challenges and perspectives. Management of Environmental Quality: An International Journal, 2006, vol. 17, no. 5, pp. 611-624. DOI: 10.1108/14777830610684576

39. Adams M. Quality of Urban Spaces and Wellbeing. Eds by R. Cooper, E. Burton, C.L. Cooper. Wellbeing, A Complete Reference Guide, vol. II, Wellbeing and the Environment. Wiley-Blackwell, 2014, 736 p. Available at: https: //onlinelibrary.wiley.com/doi/pdf/10.1002/9781118539415.wbwell064 (20.08.2018).

40. Ilina I.N. Kachestvo gorodskoi sredy kak faktor ustoichivogo razvitiya munitsipal'nykh obrazovanii [Quality of the urban environment as a factor of sustainable development of municipalities].Imushchestvennye otnosheniya v Rossiiskoi Federatsii, 2015, no. 5, pp. 69-82 (in Russian).

41. Pulyaevskaya O.V. Metody sotsial'no-psikhologicheskoi otsenki zhilykh kvartalov istoricheskoi zastroiki [Methods of socio-psychological evaluation of historical residential quarters]. Vestnik IrGTU, 2014, vol. 95, no. 12, pp. 128-134 (in Russian).

42. What is health promotion? World Health Organization. Available at: http: //www.who.int/features/qa/health-promotion/en/ (20.08.2018).

43. Link B.G., Phelan J. Social conditions as fundamental causes of disease. Journal of Health and Social Behavior, 1995, Extra Issue, pp. 80-94.

44. Shartova N.V., Vatlina T.V. Smertnost' gorodskogo naseleniya v Rossii: sovremennoe sostoyanie i regional'nye razlichiya [Mortality of urban population in Russia: current state and regional differences]. Vestnik Moskovskogo gosudarstvennogo oblastnogo universiteta. Seriya: Estestvennye nauk, 2018, no 1, pp. 66-76 (in Russian).

45. Maksimova T.M., Belov V.B., Lushkina N.P. Rasprostranennost' povedencheskikh faktorov riska i boleznei sistemy krovoobrashcheniya [The prevalence of behavioral risk factors and diseases of the circulatory system]. Problemy sotsial'noi gigieny, zdravookhraneniya i istorii meditsiny, 2014, no. 1, pp. 3-7 (in Russian).

46. Artamonova G.V., Shapovalova E.B., Maksimov S.A., Skripchenko A.E., Ogarkov M.Yu. Okruzhayushchaya sreda kak faktor riska razvitiya ishemicheskoi bolezni serdtsa $\mathrm{v}$ urbanizirovannom regione s razvitoi khimicheskoi promyshlennost'yu [Environment as a risk factor for the development of coronary heart disease in an urbanized region with a developed chemical industry]. Kardiologiya, 2012, vol. 52, no. 10, pp. 86-90 (in Russian).

47. Pogosova G.V. Depressiya - faktor riska razvitiya ishemicheskoi bolezni serdtsa i prediktor koronarnoi smerti: 10 let nauchnogo poiska [Depression as a risk factor for the development of coronary heart disease and a predictor of coronary death: 10 years of scientific research]. Kardiologiya, 2012, vol. 52, no. 12, pp. 4-11 (in Russian).

48. Risk Factors for Cancer. National Cancer Institute (USA). Available at: https: //www.cancer.gov/about-cancer/causes-prevention/risk (20.08.2018)

49. Zaytseva N.V., Ustinova O.Yu., Zemlyanova M.A., Maklakova O.A. Nauchno-metodicheskie podkhody k obosnovaniyu i organizatsii profilakticheskoi pomoshchi detyam s zabolevaniyami organov dykhaniya, assotsiirovannymi s vozdeistviem khimicheskikh faktorov sredy obitaniya [Scientific and methodical approaches to the justification and organization of preventive care for children with respiratory diseases associated with exposure to chemical environmental factors]. Gigiena $i$ sanitariya, 2014, vol. 93, no. 6, pp. 104-107 (in Russian).

50. Bilichenko T.N., Bystritskaya E.V., Chuchalin A.G., Belevskii A.S., Batyn S.Z. Smertnost' ot boleznei organov dykhaniya $\mathrm{v}$ 2014-2015 godakh i puti ee snizheniya [Death rate from respiratory diseases in 2014-2015 and ways to reduce it]. Pul'monologiya, 2016, vol. 26, no. 4, pp. 389-397 (in Russian).

51. Proekt Strategii formirovaniya zdorovogo obraza zhizni naseleniya, profilaktiki i kontrolya neinfektsionnykh zabolevanii na period do 2025 goda [Draft Strategy for Healthy Living, Prevention and Control of Noncommunicable Diseases for the period up to 2025]. Federal State Institution "National Medical Research 
Center for Preventive Medicine" of the Ministry of Healthcare of the Russian Federation: The official website. Available at: https: //www.gnicpm.ru/UserFiles/stragedy project fin 2512.pdf (20.08.2018) (in Russian).

52. World Cities Culture Report 2015. World Cities Culture Forum. Available at: http: //www.worldcitiescultureforum.com/publications/world-cities-culture-report-2015 (20.08.2018).

Prokofyeva A.V., Lebedeva-Nesevrya N.A. Creation of health-oriented city space as a way to manage population health risk. Health Risk Analysis, 2018, no. 3, pp. 144-155. DOI: 10.21668/health.risk/2018.3.16.eng

Received: 21.08.2018

Accepted: 20.09 .2018

Published: 30.09.2018 